\title{
Smoking as an Issue of Concern among School Students in an Egyptian Rural
} Area

Taghreed M. Farahat, Hala.M. Shaheen, Safa.H. Alkalsh, Nareeman. M. Bebars

Family Medicine department, Faculty of Medicine, Menoufia University.

\begin{abstract}
:
Background: Smoking is a public health problem with a rising prevalence. A large percentage of smokers start smoking during adolescence, affecting their school achievement. Objectives: The current study is aiming to 1. Assess prevalence of smoking among school students in an Egyptian rural area.2. Identify different types of smoking among them. 3. Identify the causes of being smoking an issue of concern.

Methods: the study was a cross sectional study in which sample size was calculated and three hundred students (in the academic year 201612017) were randomly selected from Monshaat Sultan preparatory and secondary school students and proportionally allocated. A predesigned questionnaire was used to determine socioeconomic status of them, pattern and condition of smoking among them. Children`s scores were revised in school records.Results: Prevalence of smoking among adolescent students was $14 \%$, about $52 \%$ of them were secondary school students, and $44.2 \%$ of them were incorporated in work. Smoking substances among smokers were cigarettes $(86 \%)$ followed by hashish (4.7\%) \& St-El hosn (4.7\%). Mean scholastic achievement among smoking students was $(2.11 \pm 0.87)$ compared to $(3.37 \pm 0.49)$ among nonsmokers and lastly the frequency of smoking among working children was high as bout $(78 \%)$ of daily smokers were working. Conclusion: This study concluded that smoking among adolescents is an issue of concern due to its prevalence, which was $14 \%$ in an Egyptian rural area also due to its drawbacks on scholastic achievements of smoking children who were incorporated in child work to get money for buying cigarettes.
\end{abstract}

Keywords: Adolescents, cigarettes, prevalence, smokers.

Introduction:Tobacco smoking epidemic is one of the biggest public health threats that world has ever faced. It is the killer of nearly six million peoples yearly and accounts for one in 10 adult deaths worldwide. ${ }^{(1)}$ Most adult smokers begin smoking during adolescence, so adolescent smoking is an issue of concern. ${ }^{(2)}$ Total tobacco consumption in Africa increased by $3.6 \%$ from 1990 to 1997. Egypt has the highest rate of tobacco consumption in the Arab world. ${ }^{(3)}$ For the period 1999-2008, World Health Organization (WHO)/Centers for Disease Control global youth tobacco survey has shown that smoking starts as early as $13-15$ years. ${ }^{(4)}$

Estimates of current cigarette smoking at this age in Eastern Mediterranean Region (EMR) nations range from $2 \%$ among girls to $7 \%$ among boys. ${ }^{(4)}$ Mean prevalence of tobacco use in 2015 was 13.6\%. ${ }^{(5)}$ Smoking in adolescence has consistently been associated with increased nicotine dependence and decreased ability of smoking cessation later in life. ${ }^{(6)}$ More than $80 \%$ of all smokers live in low-income and middle-income countries. Therefore, tobacco use continues to be a major public $\mathrm{h} *$ Corresponding author: E-mail: Dr.nareeman.2014@gmail.com ${ }^{-1}{ }^{-24}$ years are 


\section{Farahat et al: Smoking among school students}

estimated to constitute $21 \%$ of Egypt's population and by 2025, their population is projected to reach almost 18 million. ${ }^{(8)}$

Several risk factors predispose to adolescent smoking such as: social media which can normalize attitudes toward smoking, and even represent smoking as a behavioral option, ${ }^{(6)}$ parental smoking, living with a smoker or secondhand smoke exposure at home also increase risk of smoking, ${ }^{(9)}$ peers in preadolescents accounts for early smoking. ${ }^{(10)}$ Genetic factors may make quitting smoking more difficult for young people. ${ }^{(11)}$ Smoking rates are even higher among individuals with multiple lifetime psychiatric diagnoses (schizophrenia, and other severe mental illnesses). ${ }^{(12)}$ Mental illness is associated with high levels of nicotine dependence, increasing the intensity of smoking, and smoking severity and with less success in quitting. ${ }^{(13)}$

Smoking is related to many chronic diseases including coronary heart disease, stroke, chronic obstructive pulmonary disease (COPD), asthma, rheumatoid arthritis and osteoporosis. Exposure to secondhand tobacco smoke has been shown to damage the health of children and adults. ${ }^{(14)}$ Smoking promotes cancers in numerous organs, especially mouth, pharynx, pancreas and esophagus; male smokers were at higher risk for death from prostate cancer and female smokers were at higher risk for death from breast cancer. ${ }^{(15)}$ The current study is aiming to 1.Assess prevalence of smoking among school students in an Egyptian rural area.2. Identify different types of smoking among them. 3.Identify the causes of being smoking an issue of concern.

Methods: This study was approved by Ethical Committee of Faculty of Medicine, Menoufia University; an official permission letter was obtained and directed to general director of education in Menouf district, Menoufia governorate. A verbal consent was obtained from all participants after simple and clear explanation of the research objectives. Written consents were obtained from the students` parents and the school principals. The study was a cross sectional study that was conducted on preparatory and secondary school students (during the academic year 201612017) in Monshaat Sultan village, Menouf district, and Menoufia governorate.

Menoufia governorate consisted of 9 districts from them Menouf district was selected by multistage stratified sampling technique then Monshaat Sultan village was selected by simple random sampling to be the site of study.

The sample size was calculated using EPI-INFO program version (7) depending on total number of male and female students registered in preparatory and secondary 


\section{Farahat et al: Smoking among school students}

schools in academic years (2016/2017) in Monshaat Sultan during period of the study (1542 students).

The calculated sample size was 260. It was raised to 300 students to avoid drop out. Two schools were chosen randomly out of three schools; one of them was preparatory and the other one was secondary school, then a number of 112 male students (out of 300) were selected from Monshaat Sultan secondary school for boys and 188 male students (out of 742) were selected from Monshaat sultan preparatory mixed school. A number of the participants were proportionally allocated according to total number of students in each stage. Female students were excluded due to social stigma.

All students who participated in the study were evaluated using a predesigned questionnaire through direct interview with them. The questionnaire included questions about sociodemographic data like age, sex, family size...etc for assessment of socioeconomic status according to Fahmy et al, 2015. ${ }^{(16)}$ It also included questions about smoking status of the students, causes of smoking, number of cigarettes they bought...etc.

The questionnaire was revised by two expertises. A Pilot study was done with a convenient sample, which was excluded from the study (40 students) to measure the feasibility of the study setting, content and validity of the questionnaire.

The scholastic achievement was detected through revision of their school records of the first and last semesters. It was described as follows from school records ${ }^{(17)}$ as follow:- 1-Fair: 50-60(score =1) 2-Good: 60-75(score =2) 3-V.good:75-85(score =3). 4- Excellent :> 85(score $=4)$.

Data Mangement: The data were tabulated and analyzed by Statistical Package of Social Science (SPSS) version 22(using IBM personal computer). Quantitative data were expressed as mean and standard deviations and analyzed by applying student $\mathrm{t}$ test.Qualitative data were expressed and analyzed by applying Chi-square test. Pvalue (less than 0.05) was considered a statistically significant, P-value less than 0.001) was considered a highly statistically significant while P value (more than 0.05 ) was considered statistically non-significant.

Results:Mean age of the studied group was (14.77 \pm 1.47 years). $33 \%$ of their mothers had literate certificate and $41.3 \%$ of their fathers had high educational level, $80 \%$ of 
participants` mothers were housewives, $49 \%$ of the studied group used computer sometimes and $77 \%$ of them had enough income. Three -fourth of the studied group had middle socioeconomic status (Table 1). This figure shows that prevalence of smoking was 14\%among students within the studied group (Figure 1). Cigarette smoking was constituted $86 \%$ followed by hashish and St-Elhoson, which were constituted $4.7 \%$ for each among the smoking participants ( Figure 2).

There was a statistically significant difference between smoking students and non-smoking ones regarding presence of smokers among their family members (pvalue 0.045 ) as about $58 \%$ of smoking students had smokers among their family members compared to $44 \%$ in case of non-smokers also there was a statistically significant difference between smoking children regarding household member who was smoking ( $\mathrm{p}$ value 0.001) as the smoking father was more among smoking students compared to non-smoking ones (Table 2). This figure illustrates that $60 \%$ of smokers in the studied group smoked daily (Figure3).

This table shows that there was a statistically significant differences between smokers and non-smokers regarding level of education as about $52 \%$ of the smokers were in secondary schools while there were highly statistically significant differences between smokers and non-smokers regarding child work \& school achievement score (P-value $<0.001)$ as $53.5 \%$ of smokers were workers also the mean scholastic achievement among smokers was $(2.11 \pm 0.87)$ which was lower than that of nonsmokers (3.37 \pm 0.49$)$ (Table 3). It was noticed that there was a highly statistically significant difference between daily smokers and non-daily smokers regarding child work ( $\mathrm{p}$ value $<0.001)$ as about $(78 \%)$ of daily smokers were incorporated in child work (Table 4).

Discussion: This study showed that prevalence of smoking among preparatory and secondary school students was $14 \%$, this result was in agreement with Trapl, 2015(17) who found that prevalence of smoking among youth in United States of America (USA) was $14.3 \%$. Also, Al-Zalabani and Kasim,2015 (18) in Saudi Arabia who concluded that prevalence of adolescents smoking was $15.17 \%$. While this result was in controversy with the study which was conducted in Australia by Town et al,2017 (2) who reported that $3.4 \%$ of those in age group from (12-17) were daily smokers. This great difference in the prevalence of smoking may be due to strict antismoking measures in Australia. 


\section{Farahat et al: Smoking among school students}

It was found in the current study that the prevalence of smoking increased with age, as it was $41.8 \%$ among preparatory school students while it increased to reach $51.8 \%$ among secondary school students. A study was conducted by El-Gilany et al, $2008^{(19)}$ on university students concluded that the prevalence of any type of tobacco was $18.5 \%$ which is higher than the prevalence in the current study (14\%)and this is an indicator that smoking is increasing among adolescents.

Current study revealed that there was no statistically significant difference between smokers and non-smokers of participants regarding socioeconomic standard and this was not in agreement with an epidemiological surveillance which had reported higher rates of smoking among adults of lower socioeconomic status according to Hiscock etal,2012 ${ }^{(20)}$.Also a study was conducted in Saudi Arabia by AlZalabani and Kasim,2015(18) found that there was a positive association between adolescent smoking and school status, and pocket money.

On the other hand, an another study was conducted by Wellman ,2016 ${ }^{(21)}$ illustrated that an increased risk of smoking onset in USA was associated with lower Socioeconomic status. Also Chen and Jacobson, $2012^{(22)}$ found that low socioeconomic status had been associated with early cigarette use. According to the study that was conducted in Australia by Towns et al, $2017^{(2)}$ the pattern of tobacco use amongst adolescents from low socioeconomic status groups was consistently higher. The difference between current study and the previously mentioned studies may be attributed to difference in communities where the studies were conducted.

The present study showed that parental smoking greatly affected smoking status of the adolescent and this was in agreement with the study which was conducted by Liao e et al,2013 ${ }^{(23)}$ where it was found that parents influence adolescent smoking and drug use through modeling their own use as well as having substances available in the home. According to the study conducted by Pentz\&Rigg, 2013(24) both parents and peers have been shown to influence early adolescent cigarette use, as well as alcohol use. An increased risk of smoking onset was consistently (i.e., in four or more studies associated with family members'smoking, according to Wellman, 2016. ${ }^{(21)}$ According to the study that was conducted in Saudi Arabia by Al-Zalabani\&Kasim, $2015^{(18)}$ smoking among parents and friends were the most powerful predictors of adolescents smoking.

The current study showed that $60 \%$ of the smoking participants were daily smokers while $40 \%$ of them didn`t smoke daily depending on the money available for 


\section{Farahat et al: Smoking among school students}

buying the smoked substance and this was in controversy with the study which was conducted by Towns et al, $2017^{(2)}$ who found that $3.4 \%$ of adolescents were daily smokers while $1.1 \%$ were weekly smokers due to strict antismoking measures.

It was noticed that the frequency of smoking was higher among smokers who work as about $(78 \%)$ of daily smokers were incorporated in child work. On the contrary, a study was conducted by lee et al, $2017^{(25)}$ concluded that prevalence of ever conventional cigarette smokers was $17.1 \%$, and $3.7 \%$ of participants were current daily conventional cigarette smokers.

A relationship between smoking status and child work was revealed in the current study as there was a statistically significant difference between smokers and non-smokers regarding working status and as $53.5 \%$ of smokers were workers and this is in agreement with the study of Dall'Agnol et al,2011 ${ }^{(26)}$ in Brazil that found higher smoking prevalence rate among working children. Also this study showed that smoking status affects scholastic achievement of the students as there was a highly statistically significant difference between smokers and non-smokers regarding school achievement score, this result also agreed with the results of Dall'Agnol et al,2011 ${ }^{(26)}$ where child and adolescent smoking was directly associated with age , inadequate school performance.

The current study found a relationship between the frequency of smoking and the child`s working status as the frequency of smoking was higher among working students who smoked as about $78 \%$ of daily smokers were incorporated in child work. These results casted the light on the fact that those smokers continued to work to provide money to buy the smoked substances and this work affected their scholastic achievement.

Limitations of the study: There were some limitation in the current study including:1-Refusal of the students (especially smokers) to participate due to fear of disclosure of research results.2- Some teachers in the school weren`t ready to save time for the research as they thought it was of no value.3. When the researcher tried to conduct the study on females, it was considered as social stigma. The above mentioned limitations were overcome by: 1-Ensuring the confidentiality of the research study.2-Persuading the teachers with the importance of the study by explaining the burden of the smoking problem on the community.3-Exclusion of female from the study. 
Conclusion: This study concluded that smoking among adolescents is an issue of concern due to its prevalence that was $14 \%$ in an Egyptian rural area also due to its drawbacks on scholastic achievements of smoking children who were incorporated in child work to get money for buying cigarettes so daily smoking was higher among working students.

Funding: There has been no financial support for this work that could have influenced its outcome.

Conflict of interests: We confirm that there are no known conflicts of interest associated with this publication.

Acknowledgment: I would like to express my deepest gratitude and sincere appreciation to my professors Prof. Taghreed Mohammed Farahat (Professor of Family Medicine. Faculty of Medicine. Menoufia University), Prof. / Hala Mohamed ElMoselhi Shaheen (Professor and Head of Family Medicine ,Faculty of Medicine ,Menoufia University) and Dr.Safa Hamdy Alkalsh (lecturer of Family Medicine, Faculty of Medicine, Menoufia University) for their continuous encouragement, kind support and continuous guidance throughout this work. Also I owe great and deep thanks to the children, Parents and teachers who participated in this work and from whom I learned much.

\section{References:}

1. Bhat M. A., Rashid H., Hamid S., Hamid, S., Ali S., Khursheed R. Smoking behaviour among young doctors of a tertiary care hospital in North India. International Journal of Research in Medical Sciences 2017; 2(3): 102630 .

2. Towns S., DiFranza J., Jayasuriya G., Marshall T., Shah S. Smoking Cessation in Adolescents: targeted approaches that work. Paediatric respiratory reviews2017; 22: 11-22.

3. Nassar H. The economics of tobacco in Egypt: a new analysis of demand. Economic of tobacco control 2003; 8:28.

4. Mandil A., Bin Saeed A., Dabbagh R., Shaikh S. A., Al Saadi M., Khan M. Smoking among Saudi university students: consumption patterns and risk factors 2011; 17(4):309-16.

5. Xi B., Liang Y., Liu Y., Yan Y., Zhao M., Ma C. et al. Tobacco use and secondhand smoke exposure in young adolescents aged 12-15 years: data from 68 lowincome and middle-income countries. The Lancet Global Health 2016; 4(11), 795-805. 
6. Cambron C., Kosterman R., Catalano R., Guttmannova K., Hawkins J. Neighborhood, family, and peer factors associated with early adolescent smoking and alcohol use. Journal of youth and adolescence2018;47(2), 369-82.

7. Ng M, Freeman M, Fleming T, Robinson M, Dwyer-Lindgren L, Thomson B et al. Smoking prevalence and cigarette consumption in 187 countries, 1980-2012. JAMA. 2014 Jan 8;311(2):183-92. PMID: 24399557

8. Depue J., Southwell B., Betzner A., Walsh B. Encoded exposure to tobacco use in social media predicts subsequent smoking behavior. American Journal of Health Promotion2015; 29(4): 259-61.

9. Sylvestrea W, Dugas L. Gender differences in risk factors for cigarette smoking initiation in childhood addictive behavior2017;72:144-50.

10. Milton B., Woods S., Dugdill L., Porcellato L., Springett R. Starting young? Children's experiences of trying smoking during pre-adolescence. Health Education Research 2007; 23(2):298-309.

11. Chen L., Horton A., Bierut L. Pathways to precision medicine in smoking cessation treatments. Neuroscience letters2018; 669: 83-92.

12. Vanable P., Carey M., Carey K., Maisto S. Smoking among psychiatric outpatients: relationship to substance use, diagnosis, and illness severity. Psychology of Addictive Behaviors2003; 17(4): 259.

13. McClave A., McKnight-Eily L., Davis S., Dube S. Smoking characteristics of adults with selected lifetime mental illnesses: results from the 2007 National Health Interview Survey. American journal of public health2010;100(12), 246472.

14. Centers for Disease Control and Prevention. "How tobacco smoke causes disease: The biology and behavioral basis for smoking-attributable disease: A report of the surgeon general." (2010).

15. Thun M., Carter B., Feskanich D., Freedman N., Prentice R., Lopez, A.et al. 50year trends in smoking-related mortality in the United States. New England Journal of Medicine2013; 368(4): 351-64.

16. Fahmy S., Nofal, L., Shehata S., El Kady H., Ibrahim H. Updating indicators for scaling the socioeconomic level of families for health research. Journal of the Egyptian Public Health Association 2015;90(1): 1-7.

17. Trapl E., Yoder L, Frank J., Borawski E., Sattar, A. Individual, parental, and environmental correlates of cigar, cigarillo, and little cigar use among middle school adolescents. Nicotine \& Tobacco Research2015; 18(5): 834-41.

18. Al-Zalabani A., Kasim K. Prevalence and predictors of adolescents' cigarette smoking in Madinah, Saudi Arabia: a school-based cross-sectional study. BMC public health 2015; 15(1): 17.

19. El-Gilany A-H, Badawi Karima A., El-Fedawy S. "Tobacco smoking among adolescent students in Mansoura, Egypt." Paediatrics ME 2008:13.3 : 70-8. 
20. Hiscock R., Bauld L., Amos A., Fidler J., Munafò, M. Socioeconomic status and smoking: a review. Annals of the New York Academy of Sciences 2012; 1248(1):107-23.

21. Wellman R., Dugas E., Dutczak H., O’Loughlin E., Datta G., Lauzon, B. et al. Predictors of the Onset of Cigarette Smoking. American journal of preventive medicine 2016; 51(5):767-78.

22. Chen P., Jacobson K. C. Developmental trajectories of substance use from early adolescence to young adulthood: Gender and racial/ethnic differences. Journal of adolescent health 2012; 50(2):154- 63.

23. Liao Y., Huang Z., Huh J., Pentz M., Chou C. Changes in friends' and parental influences on cigarette smoking from early through late adolescence. Journal of Adolescent Health2013;53(1), 132-38.

24. Pentz M., Riggs N. Longitudinal relationships of executive cognitive function and parent influence to child substance use and physical activity. Prevention Science2013; 14(3): 229-37.

25. Lee J., Lee S., Cho, H. The relation between frequency of e-cigarette use and frequency and intensity of cigarette smoking among South Korean adolescents. International journal of environmental research and public health 2017;14(3): 305.

26. Dall'Agnol M., Fassa A. C., Facchin, L. (2011): Child and adolescent labor and smoking: a cross-sectional study in southern Brazil. Cadernos de Saúde Pública, 27(1), 46-56. 
Farahat et al: Smoking among school students

Table (1): Smoking and sociodemographic data of the studied group.

\begin{tabular}{|c|c|c|c|c|c|c|c|c|}
\hline \multirow[t]{2}{*}{ Items } & \multicolumn{2}{|c|}{$\begin{array}{l}\text { Non } \\
\text { smokers }\end{array}$} & \multicolumn{2}{|c|}{ Smokers } & \multicolumn{2}{|c|}{ Total } & \multirow{2}{*}{$\begin{array}{l}\text { Test of } \\
\text { significance } \\
\mathbf{x}^{2}\end{array}$} & \multirow[t]{2}{*}{ P-value } \\
\hline & $\begin{array}{l}\text { No } \\
257\end{array}$ & $\begin{array}{l}\% \\
85.67\end{array}$ & $\begin{array}{l}\text { No } \\
43\end{array}$ & $\begin{array}{l}\% \\
14.33\end{array}$ & $\begin{array}{l}\text { No } \\
300\end{array}$ & $\begin{array}{l}\% \\
100\end{array}$ & & \\
\hline $\begin{array}{l}\text { Age } \\
\text {. Mean } \pm \text { SD }\end{array}$ & \multicolumn{2}{|c|}{$\begin{array}{l}14.794 \pm \\
1.474\end{array}$} & \multicolumn{2}{|c|}{$\begin{array}{l}14.628 \pm \\
1.448\end{array}$} & \multicolumn{2}{|c|}{$\begin{array}{l}14.77 \pm \\
1.469\end{array}$} & 0.685 & 0.494 \\
\hline $\begin{array}{l}\text { Mother's education } \\
\text { - Literate certificate } \\
\text { - Primary } \\
\text { - Preparatory } \\
\text { - Secondary } \\
\text { - High education }\end{array}$ & $\begin{array}{l}83 \\
52 \\
44 \\
52 \\
26\end{array}$ & $\begin{array}{l}32.3 \\
20.23 \\
17.12 \\
20.23 \\
10.12\end{array}$ & $\begin{array}{l}16 \\
11 \\
7 \\
5 \\
4\end{array}$ & $\begin{array}{l}37.21 \\
25.58 \\
16.28 \\
11.63 \\
9.3\end{array}$ & $\begin{array}{l}99 \\
63 \\
51 \\
57 \\
30\end{array}$ & $\begin{array}{l}33 \\
21 \\
17 \\
19 \\
10\end{array}$ & 3.129 & 0.68 \\
\hline $\begin{aligned} \text { Father's education } \\
\text { - } \\
\text { - Piterate certificate } \\
\text { - } \text { Prepary } \\
\text { - } \text { Secondary } \\
\text { High education }\end{aligned}$ & $\begin{array}{l}52 \\
15 \\
30 \\
50 \\
110\end{array}$ & $\begin{array}{l}20.23 \\
5.84 \\
11.67 \\
19.46 \\
42.8\end{array}$ & $\begin{array}{l}14 \\
1 \\
8 \\
6 \\
14\end{array}$ & $\begin{array}{l}32.56 \\
2.33 \\
18.6 \\
13.95 \\
32.56\end{array}$ & $\begin{array}{l}66 \\
16 \\
38 \\
56 \\
124\end{array}$ & $\begin{array}{l}22 \\
5.33 \\
12.67 \\
18.67 \\
41.33\end{array}$ & 10.816 & 0.094 \\
\hline $\begin{array}{c}\text { Mother's work } \\
\text { - No } \\
\text { - Yes }\end{array}$ & $\begin{array}{l}208 \\
49\end{array}$ & $\begin{array}{l}80.93 \\
19.07\end{array}$ & $\begin{array}{l}32 \\
11\end{array}$ & $\begin{array}{l}74.42 \\
25.58\end{array}$ & $\begin{array}{l}240 \\
60\end{array}$ & $\begin{array}{l}80 \\
20\end{array}$ & 0.977 & 0.214 \\
\hline $\begin{array}{c}\text { Father's work } \\
\text { - No } \\
\text { - } \quad \text { Yes }\end{array}$ & $\begin{array}{l}17 \\
240\end{array}$ & $\begin{array}{l}6.61 \\
93.39\end{array}$ & $\begin{array}{l}3 \\
40\end{array}$ & $\begin{array}{l}6.98 \\
93.02\end{array}$ & $\begin{array}{l}20 \\
280\end{array}$ & $\begin{array}{l}6.67 \\
93.33\end{array}$ & 0.008 & 0.568 \\
\hline $\begin{array}{ll}\text { Computer uses } \\
\text { - } & \text { Never } \\
\text { - } & \text { Sometimes } \\
\text { A lot of time }\end{array}$ & $\begin{array}{l}40 \\
120 \\
97\end{array}$ & $\begin{array}{l}15.56 \\
46.69 \\
37.74\end{array}$ & $\begin{array}{l}2 \\
27 \\
14\end{array}$ & $\begin{array}{l}4.65 \\
62.79 \\
32.56\end{array}$ & $\begin{array}{l}42 \\
147 \\
111\end{array}$ & $\begin{array}{l}14 \\
49 \\
37\end{array}$ & 5.349 & 0.069 \\
\hline $\begin{array}{l}\text { Income } \\
\text { - Not enough } \\
\text { - Enough }\end{array}$ & $\begin{array}{l}62 \\
195\end{array}$ & $\begin{array}{l}24.12 \\
75.88\end{array}$ & $\begin{array}{l}7 \\
36\end{array}$ & $\begin{array}{l}16.28 \\
83.72\end{array}$ & $\begin{array}{l}69 \\
231\end{array}$ & $\begin{array}{l}23 \\
77\end{array}$ & 1.28 & 0.176 \\
\hline \begin{aligned} & \multicolumn{2}{l}{ Socioeconomic status } \\
& - Low \\
& - Middle \\
& - High \end{aligned} & $\begin{array}{l}64 \\
193 \\
0\end{array}$ & $\begin{array}{l}24.9 \\
75.1 \\
0.00\end{array}$ & $\begin{array}{l}14 \\
29 \\
0\end{array}$ & $\begin{array}{l}32.56 \\
67.44 \\
0.00\end{array}$ & $\begin{array}{l}78 \\
222 \\
0\end{array}$ & $\begin{array}{l}26 \\
74 \\
0.00\end{array}$ & 1.122 & 0.19 \\
\hline
\end{tabular}

$P$ value $<0.05$ is statistically significant 
Farahat et al: Smoking among school students

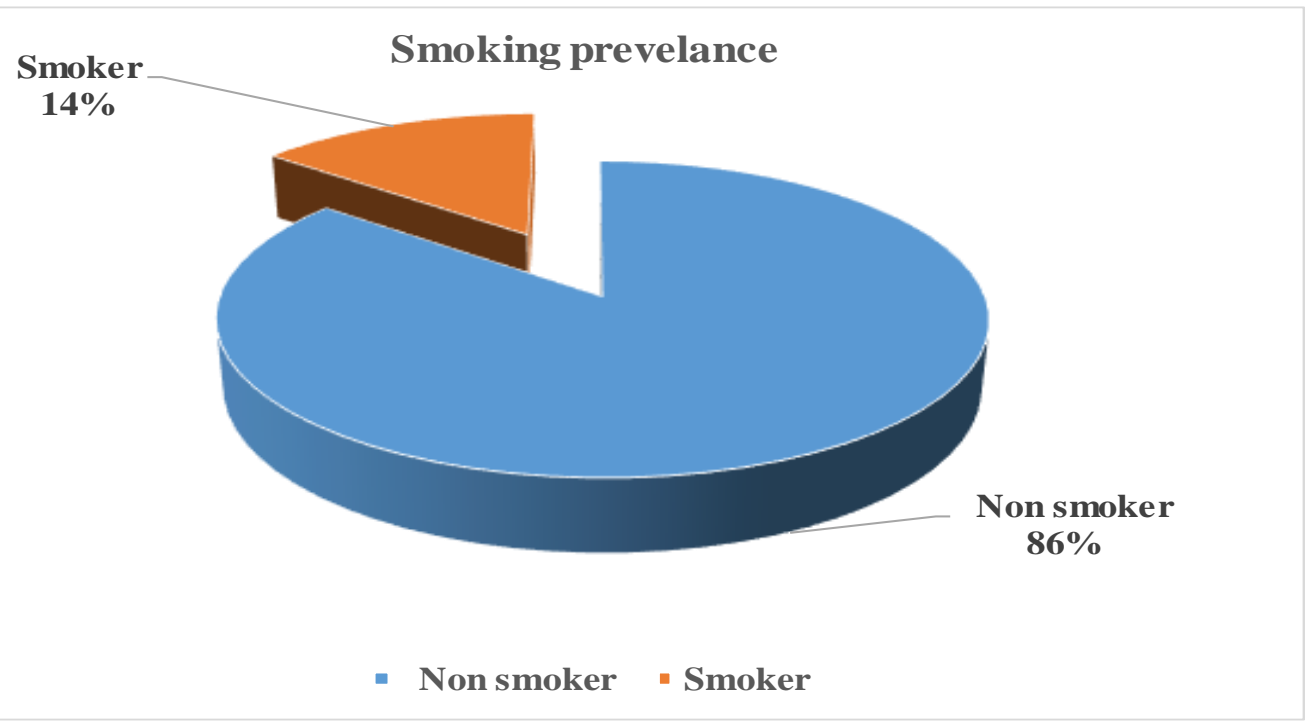

Figure(1): Prevalence of smoking

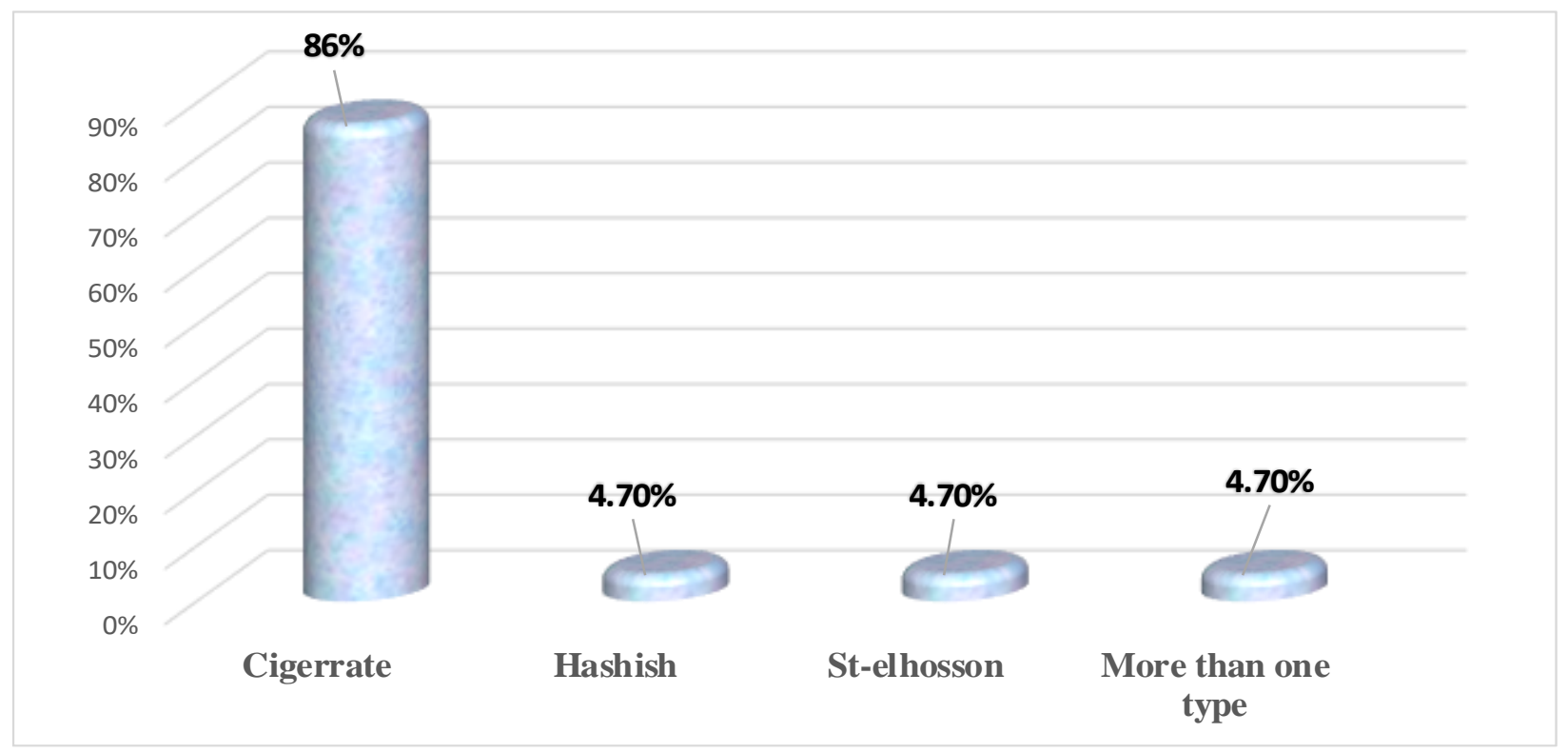

Figure(2): Types of smoked substances 
Farahat et al: Smoking among school students

Table (2): Smoking among household of the studied group

\begin{tabular}{|c|c|c|c|c|c|c|c|c|}
\hline \multirow{2}{*}{ Items } & \multicolumn{2}{|c|}{$\begin{array}{l}\text { Non } \\
\text { smokers }\end{array}$} & \multicolumn{2}{|c|}{ Smokers } & \multicolumn{2}{|c|}{ Total } & \multirow{2}{*}{$\mathbf{X}^{2}$} & \multirow{2}{*}{ P-value } \\
\hline & $\begin{array}{l}\text { No } \\
257\end{array}$ & $\begin{array}{l}\% \\
85.67\end{array}$ & $\begin{array}{l}\text { No } \\
43\end{array}$ & $\begin{array}{l}\% \\
14.33\end{array}$ & $\begin{array}{l}\text { No } \\
300\end{array}$ & $\begin{array}{l}\% \\
100\end{array}$ & & \\
\hline $\begin{array}{l}\text { Smoking among family } \\
\text { members: } \\
\text { - No } \\
\text { - Yes }\end{array}$ & $\begin{array}{l}145 \\
112\end{array}$ & $\begin{array}{l}56.42 \\
43.58\end{array}$ & $\begin{array}{l}18 \\
25\end{array}$ & $\begin{array}{l}41.86 \\
58.14\end{array}$ & $\begin{array}{l}163 \\
137\end{array}$ & $\begin{array}{l}54.33 \\
45.67\end{array}$ & 3.147 & $0.045^{*}$ \\
\hline \begin{tabular}{|cl} 
Family members who \\
smoke \\
- Father \\
- Brother \\
- Others \\
\end{tabular} & $\begin{array}{l}53 \\
20 \\
39 \\
\end{array}$ & $\begin{array}{l}20.62 \\
7.78 \\
15.18\end{array}$ & $\begin{array}{l}20 \\
4 \\
1\end{array}$ & $\begin{array}{l}46.51 \\
9.3 \\
2.33 \\
\end{array}$ & $\begin{array}{l}73 \\
24 \\
40\end{array}$ & $\begin{array}{l}24.33 \\
8 \\
13.33\end{array}$ & 16.252 & $0.001 *$ \\
\hline
\end{tabular}

$P$ value $<0.05$ is statistically significant

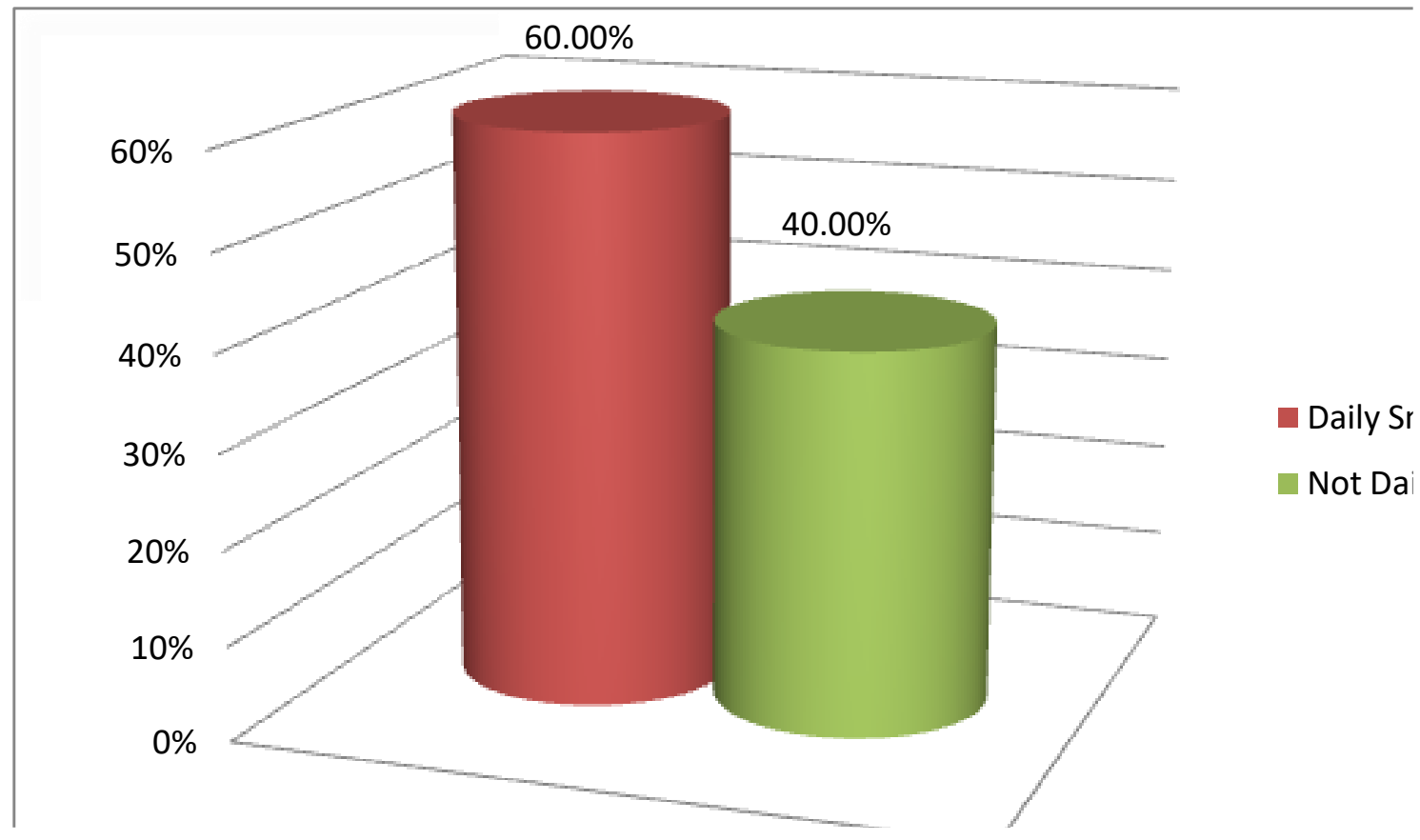

Figure (3): Frequency of smoking among studied smokers 
Farahat et al: Smoking among school students

Table(3): Comparison between smokers and non-smokers regarding Educational level \& Child work and their Scholastic achievement

\begin{tabular}{|c|c|c|c|c|}
\hline Smoking status & $\begin{array}{l}\text { Smokers } \\
\mathrm{N}=43\end{array}$ & $\begin{array}{l}\text { Non smokers } \\
\mathbf{N}=\mathbf{2 5 7}\end{array}$ & $\mathrm{X}^{2}$ test & $P$ value \\
\hline $\begin{array}{c}\text { Educational level } \\
\text { preparatory } \\
\text { Secondary }\end{array}$ & $\begin{array}{ll}18 & (41.8 \%) \\
25 & (51.8 \%)\end{array}$ & $\begin{aligned} 170 & (66.1 \%) \\
87 & (33.9)\end{aligned}$ & 9.28 & $0.002 *$ \\
\hline $\begin{array}{c}\text { Child work } \\
\text { - No } \\
\text { - } \quad \text { Yes }\end{array}$ & $\begin{array}{ll}20 & (46.5 \%) \\
23 & (53.5 \%)\end{array}$ & $\begin{array}{ll}227 & (88.3 \%) \\
30 & (11.7 \%)\end{array}$ & 44.28 & $<0.001 * *$ \\
\hline $\begin{array}{l}\text { Scholastic achievement } \\
\text { score }(\text { Mean } \pm \text { SD) }\end{array}$ & $2.11 \pm 0.87$ & $3.37 \pm 0.49$ & $13.5^{\mathrm{a}}$ & $<0.001 * *$ \\
\hline
\end{tabular}

a: t- test

$* * \mathrm{P}$ value $<0.001$ highly statistically significant

$* \mathrm{P}$ value $<0.05$ statistically significant

Table 4: Relation between frequency of smoking and child work among smokers

\begin{tabular}{|c|c|c|c|c|}
\hline Frequency of smoking & $\begin{array}{l}\text { Daily smoking } \\
\qquad \text { N (23) }\end{array}$ & $\begin{array}{c}\text { Not daily smoking } \\
\text { N (20) }\end{array}$ & $\mathbf{X}^{2}$ & $P$ value \\
\hline $\begin{array}{r}\text { Child work } \\
\text { - No } \\
\text { - Yes }\end{array}$ & $\begin{array}{ll}5 & (21.7 \%) \\
18 & (78.2 \%)\end{array}$ & $\begin{array}{ll}13 & (65 \%) \\
7 & (35 \%)\end{array}$ & 58.35 & $<0.001 * *$ \\
\hline
\end{tabular}

** $\mathrm{P}$ value $<0.001$ highly statistically significant 


\section{الملخص العربي}

\section{التدخين كمسألة مثيرة للقلق بين طلاب المدارس في منطقة ريفية مصرية}

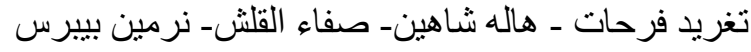

الخلفية: التخخين مشكلة صحية عامة مع انتشار متزايد. وتبدأ نسبة كبيرة من المدخنين التنخين خلال فترة المر اهقة ، مما يؤثر على تحصيلهم الدراسي.و هدفت هذه الدراسه الي_1 ـ تقييم انتشار التدخين بين طلاب المدارس الإعدادية و الثانوية في منطقة ريفية مصرية.2 .تحديد أنواع مختلفة من التدخين فيما بينها.3. تحديد الأسباب التي تجعل من التدخين قضية ذات أهمية. المنهجية و طرق البحث تم حساب حجم العينة وتم اختيار ثلاثمائة طالب بشكل عشو ائي من طلاب مدارس منشأة سلطان الإعدادية و الثانوية وتم تخصيصهم بشكل نسبي. تم استخدام استبيان محدد مسبقا لتحديد الوضع الاجتماعي الاقتصادي لهم ، نمط وحالة التنخين فيما بينهم. ثم تم تنقيح نتائج الأطفال في السجلات المدرسية.النتائج: بلغت نسبة انتشار التنخين بين المر اهقين 14٪ ، وكان حو الي 52٪ منهم من طلاب الددارس الثانوية ، منهم 44.2٪ يعملون. وكانت اعلى نسبة للتندين بين المدخنين هي للسجائر (86\%) يليها الحشيش (4.7\%) وست الحسن (4.7٪) و أكثر من نوع واحد (4.7٪). بلغ منوسط الإنجاز المدرسي بين الطلاب المدخنين (2.11 \& 0.87) مقارنة بـ (3.37 ـ 0.49) بين غير المدخنين وأخيراً التدخين في أوساط الأطفال العاملين حيث وجد ان 78٪ من المدخنين بصورة يومية يعملون.الخلاصة: خلصت هذه الدراسة إلى أن التدخين بين المر اهقين هو مصدر قلق بسبب انتشاره والذي كان 14٪ في منطقة ريفية

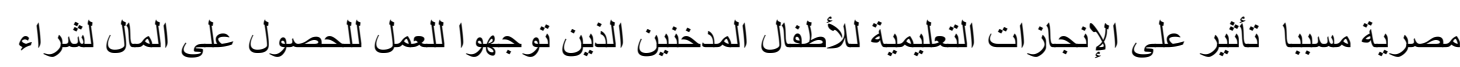
السجائر. كان التدخين اليومي أعلى بين الطلاب العاملين. 